\title{
The 1990s Assault on Juvenile Justice: Notes from an Ideological Battleground
}

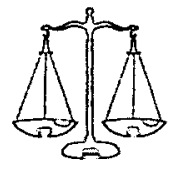

FRANKLIN E. ZIMRING

William G. Simon

Professor of Law and

Director of the Earl

Warren Legal Institute,

University of Califor.

nia, Berkeley
The 1990s have witnessed the broadest and most sustained legislative crackdown ever on serious offenses committed by youth within the jurisdictional ages of American Juvenile Courts. More than $90 \%$ of the states in the United States have passed new laws facilitating transfer of youth to criminal courts, reducing privacy protections in juvenile court or increasing the punishment power of special branches of the juvenile court. Republican majorities in the federal congress have persistently proposed financial aid inducements for the states to increase punishments for adolescent offenders. The sustained attention to adolescent crime is also giving the minuscule federal court juvenile justice caseload a higher profile than ever before. With about 200 cases per year in the federal courts, or about I for every 3,500 delinquency cases in the states, the federal juvenile justice caseload has nonetheless been proposed as a subject for legislatively required sentencing guidelines to be issued by the United States Sentencing Commission. Evidently no caseload is too small to play a role in the epic legislative battle that is being waged against youth crime in the I990s.

But why the I990s? The last time juvenile crime was a central media and public concern was 1975 . when the population of $13-17$ year olds reached its all time peak in the United States. While a few states made large legal changes in the late 1970s, the movement to crack down lasted about half as long as the current legislative open season and was never as broad as in the I990s. ${ }^{\text {. }}$

The standard explanation for the youth crime scare of the 1990 os has been a public and legislative reaction to escalating rates of serious youth violence. Between I980 and I993 adolescent arrests for homicide more than doubled and this increase provoked projections of further increases in future years. Terms like "bloodbath," "coming storm of juvenile violence" and "juvenile super-predator" gained currency in the discussion of youth crimes within the legislative process. ${ }^{2}$

But there are substantial flaws in the theory that increasing rates of youth violence were the driving force behind the decade-long counter-reformation in juvenile justice. For starters, the youth homicide rate peaked in 1993 and has been dropping fast ever since then with no parallel relaxation in the assault on the juvenile justice system. And the increases in homicides were concentrated in very large cities; many of the jurisdictions that passed new laws never had a juvenile crime wave to call their own. By 1996 and 1997, crime rates and victimization levels were down but the legislative pressure remained extraordinary.

The new threat supporting "get tough" legislation was a future expansion expected of the youth population (about $15 \%$ in I5 years) that citizens were told would bring with it a "coming storm of juvenile violence," in the oft repeated phrase of Representative Bill McCullum of Florida. In the middle of the largest sustained decline in violent crime in 30 years, these predictions of "a coming storm" suggest that the holy war about juvenile justice was neither wholly nor mainly a reaction to levels of crime in the streets. When the youth crime increases of the late 1980 s fell back, the hard line advocates simply created a projected crime scare in the future. With this kind of resourcefulness, the campaign to criminalize the juvenile justice system never needed a body count.

I would like to suggest that the focus on juvenile justice in the r 990 os can best be understood as an integral part of the ideological battle about imprisonment and official attitudes toward crime. In the two decades prior to the early I990s, penal policy had been effectively reoriented to hard line objectives in the United States, and this shift was more than rhetorical. From its low point in 1973, the United States prison population has risen without interruption for more than a quarter century. American prisons held more than four times as many inmates in 1997 as in 1973 , and this expansion was an explicit objective of the criminal justice policy in force in almost all the states.

It turns out that the juvenile courts were a hold-out against the law-and-order reorientation occurring elsewhere in the American criminal justice system, a contrast in both rhetoric and behavior to the spiral of increased incarceration. To be sure, secure confinement in both pre-trial detention and longer term reformatories had always been an important element of juvenile justice in the United States, and rates of confinement for older juveniles were quite close to those for young adults in the early I970s. But the trend in juvenile justice over the last two decades is a sharp contrast to that of the criminal courts. Figure I contrasts trends in confinement of older juveniles with confinement rates for young adults between I97I and I99I.

While the confinement rate in ages 18 to 24 doubled, the trend for juveniles $\mathrm{I} 4$ to $\mathrm{I} 7 \mathrm{years}$ of age was flat over the same period. In this important sense, the juvenile court was the only major hold-out in the law-andorder revolution in the United States. However close 
the juvenile and criminal courts had been in policy in the early I970s, Figure I shows the growing gap between the two system over the two decades just preceding the crusade against youth crime in the I99os.

While there is some controversy about the extent to which juvenile courts protected young offenders from harsh punishments over earlier periods of the twentieth century, the divergent trends between juvenile and criminal court sentencing since the early I970s could not be clearer. The two major systems for responding to youth crime in the United States were heading in sharply different directions over the I970s and I980s. It was not merely a contrast in ideology that characterized this period but a conflict as well in case outcome.

Under these circumstances, an attack on the premises and case outcomes of the Juvenile Court was probably inevitable. It was inherent in the contrast in policies between juvenile and criminal courts even without reference to crime rates. The law and order attack on juvenile justice was that juvenile courts failed to implement the crime control paradigm that was dominant throughout the criminal justice system. The hard line view has always been that young criminals are a subset of the criminal classes rather than a separate group or a separate policy problem. The rhetorical significance of the "juvenile super-predator" was his solely criminal identity. The idea was to redefine youth crime as only a problem concerning crime and criminals. Once that was accomplished, the pervasive law

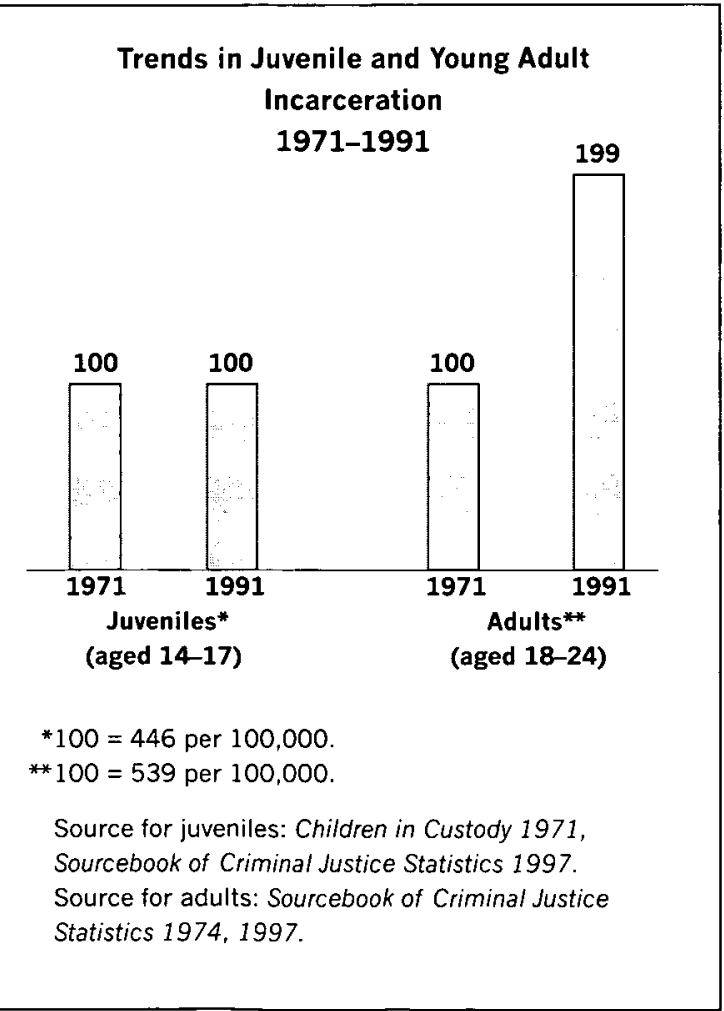

and order ethos that had been established in the prior quarter century would guarantee a hard line result.

The singular practical and ideological importance of establishing juvenile offending within the dominant crime paradigm might explain the puzzling emphasis in the Republican federal juvenile crime legislation on making the tiny trickle of under 18 cases into a subject for special federal sentencing guidelines. The symbolic importance of juvenile sentencing guidelines would be the transformation of juvenile delinquency into a branch of crime control policy, just another crime category to be dealt with by the agency that public law had established to determine the punishments for all classes of federal crime. From this viewpoint, shifting the problem into the mechanics of the sentencing guideline system amounts to a claim that juvenile offenders lack the special status that protected them from the hard line shifts of the prior decades.

If I am right in supposing that it was the dissonance of juvenile court policy that was the proximate cause of the I990s war on youth crime, there is one irony in the attack. Were high rates of youth crime the real cause of the attack on juvenile courts, it would be fair to argue that juvenile courts were being attacked because they had failed to respond effectively to the crime threat. But since the juvenile court had set out to moderate the punishment of young offenders before it, an attack on such courts based on the fact that their policies diverge from the penal nature of today's criminal courts, meant that the juvenile court was being blamed for living up to its ambitions of moderating juvenille sentences. The effective cause of the I990s attack was not the failures of American juvenile courts but rather an objection to the successes of the courts in defining their mission as unique and protecting their subjects from the over-reach of American imprisonment.

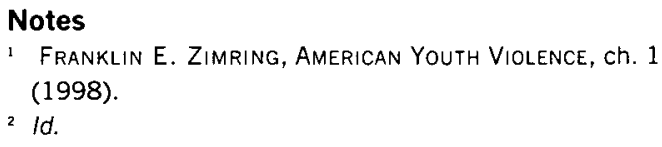

